ARTIGO

ARTICLE

\section{O marco inicial da vida humana: perspectivas ético-jurídicas no contexto dos avanços biotecnológicos}

The beginning of human life: ethical and legal perspectives in the context of biotechnological progress

El marco inicial de la vida humana: perspectivas ético-jurídicas en el contexto de los avances biotecnológicos
Vicente de Paulo Barretto 1

Elis Cristina Uhry Lauxen 1,2

\title{
Resumo
}

As indagações com relação ao termo inicial da vida humana perpassam a sociedade desde a antiguidade. No mundo pós-moderno, os avanços da ciência e da técnica potencializam as discussões acerca do tema, de modo que os debates que anteriormente se concentravam em torno do aborto, também passaram a ter como objeto as intervenções da biotecnologia. O presente artigo trata do último aspecto, a saber, refletir em que medida a dignidade humana pode ser considerada um referencial (hermenêutico) na construção de parâmetros ético-jurídicos para os avanços biotecnológicos na definição do marco inicial da vida humana. Para desenvolver a pesquisa, utilizou-se como método de abordagem a ética hermenêutica crítica, mediante a qual a ética encontra-se no centro do processo de compreensão e interpretação, observando-se os contornos da facticidade. Constatou-se que não há consenso no que diz respeito ao termo inicial da vida, de forma que é fundamental dialogar com a nova realidade decorrente dos avanços biotecnológicos, no processo de construção de preceitos éticos e jurídicos de proteção do embrião e da natureza humana, tendo como referencial a dignidade humana.

Embrião Humano; Biotecnologia; Bioética

Correspondência

E. C. U. Lauxen

Rua Pedro Weingartner 140, apto. 1204, Porto Alegre, RS 90430-140, Brasil.

eclauxen@gmail.com

1 Universidade do Vale do Rio dos Sinos, São Leopoldo, Brasil. 2 Universidade de Santa Cruz do Sul, Santa Cruz do Sul, Brasil. 


\section{Introdução}

Quando inicia a vida humana? A indagação, que permeia a sociedade desde a antiguidade, é um dos temas mais relevantes e controversos da atualidade. Em decorrência dos avanços tecnocientíficos, as dúvidas relacionadas ao marco inicial da vida, que se concentravam no aborto, também passaram a ter como objeto a implementação dos avanços biotecnológicos. Assim, os debates contemporâneos abrangem, precipuamente, dois aspectos: a interrupção da gestação e as intervenções das biotecnologias no embrião humano.

No presente artigo, tratar-se-á do segundo aspecto, que diz respeito à definição do marco inicial da vida no âmbito dos avanços biotecnológicos. Em que pese a importância do progresso da ciência no âmbito da saúde e da vida humana, inquietações decorrem das crescentes possibilidades de interferência no embrião, tais como manipulação genética, criopreservação, seleção, destruição, descarte, ingerência na natureza humana etc.

O objetivo é refletir, com base na ideia de dignidade humana, sobre aspectos éticos e jurídicos de questões relacionadas ao marco inicial da vida humana no contexto da sociedade tecnocientífica contemporânea. Para desenvolver o objetivo proposto, será usado como método de abordagem a ética hermenêutica crítica, indicada por Jesús Conill Sancho. A proposta é inovadora e utiliza a ética como orientadora do juízo reflexionante no processo interpretativo. A reflexão, com base em fundamentos éticos, observando os contornos da experiência e da historicidade, é empregada como guia para o desvelamento de sentido ${ }^{1}$.

Segundo Conill Sancho, diante do progresso científico, é preciso refletir e propor medidas que valorizem a relevante contribuição dos respectivos avanços, mas que também promovam uma orientação responsável do seu crescente poder. É necessário, ainda, enfrentar o pluralismo moral e seus inevitáveis conflitos, especialmente diante da liberdade científica. Desse modo, a ética hermenêutica é indicada como um marco de reflexão para compreender e orientar a ação tecnológica 2 .

O respectivo processo hermenêutico promove reflexões acerca da complexidade da realidade, observando os contextos históricos e culturais, as situações fáticas, as crenças e os valores. Afora os mencionados aspectos, realiza uma análise racional que incorpora a fase crítica, de discernimento e justificação da legitimidade das novas propostas, que consiste na ética hermenêutica com sentido crítico. Desse modo, Conill Sancho propõe uma ética hermenêutica crítica ${ }^{3}$. Nesta linha de raciocínio, investigar-se-á em que medida a dignidade humana pode ser considerada um referencial (hermenêutico) para a construção de parâmetros aos avanços biotecnológicos que dão causa a questionamentos acerca do marco inicial da vida humana.

\section{As biotecnologias relacionadas ao início da vida humana}

O desenvolvimento da ciência e da técnica promove abrangentes avanços na área da biomedicina. No que tange às técnicas relacionadas ao início da vida humana, pode-se apontar, especialmente, a engenharia genética, as técnicas de reprodução humana assistida, o diagnóstico genético de pré-implantação, a clonagem, a utilização de células-tronco embrionárias em pesquisas, a biologia sintética e o sistema CRISPR-Cas9 (Clustered Regularly Interspaced Short Palindromic Repeats - Cas9 Associated; em português, Repetições Palindrômicas Curtas Agrupadas e Regularmente Interespaçadas - Associadas à Proteína 9).

A propósito, ao discorrer acerca do aborto e da eutanásia como questões altamente discutidas, Ronald Dworkin 4 assinalou a possibilidade de os mencionados problemas passarem a ser considerados relativamente naturais quando confrontados com novas questões no controle do ser humano sobre sua própria reprodução. Tais demandas, conforme descreveu o mencionado autor, seriam provocadas em decorrência dos avanços técnicos na genética e na reprodução. Confirmando as respectivas previsões, os assuntos relacionados à reprodução assistida e às intervenções genéticas nas primeiras fases do desenvolvimento humano estão entre os maiores dilemas, visto que, se por um lado os respectivos avanços promovem crescentes benefícios à vida e à saúde da humanidade, por outro, podem desencadear riscos físicos ao embrião e problemas éticos que precisam ser ponderados. 
As técnicas da engenharia genética, em que pesem os relevantes melhoramentos que proporcionam à humanidade, possibilitam práticas discutíveis ${ }^{5}$. Nessa linha, são criticados procedimentos para escolha do sexo, definição de características genéticas, físicas e cognitivas ${ }^{6}$, mediante arguição de manipulação da natureza humana, assim como de interesses econômicos, políticos, militares etc. Sob outro prisma, o aperfeiçoamento genético é entendido como moralmente justificável, porquanto expressa a essência criativa do ser humano, cuja inteligência precisa ser aprimorada para acompanhar a velocidade e complexidade da biotecnologia 7 . Portanto, a concepção essencialista da natureza humana é contestada pela concepção adaptativa da biologia evolutiva, no sentido de que a existência humana se manifesta pela capacidade de modificar-se de acordo com o ambiente e não por se manter inalterada.

No que se refere especificamente à reprodução humana assistida, é inegável sua contribuição para a solução dos problemas de infertilidade e de doenças. Todavia, suscitam questionamentos os procedimentos de redução embrionária, seleção, descarte e criopreservação ininterrupta de embriões, manipulação genética, utilização e destruição de embriões em pesquisas ou até mesmo a produção de um número desnecessário de embriões para finalidades estranhas à procriação, tais como, cosméticas, industriais ou de extração de tecidos para transplantes ${ }^{8}$. Não obstante a sua relevância, a legislação brasileira é incipiente acerca do assunto, pois o Código Civil ${ }^{9}$ prevê somente em três incisos do artigo 1.597 disposições que pouco contribuem para a solução de controvérsias relacionadas ao tema e os projetos de lei referentes a ele permanecem em tramitação. Por sua vez, a Resolução CFM no 2.121/ 2015 10, que adota normas éticas para as técnicas de reprodução assistida, não abrange importantes questões, porquanto não são de sua competência e, sem embargo da relevância e da eficácia da normativa no âmbito de sua incidência, não se reveste das características próprias da norma jurídica, necessárias para resolver problemas e conflitos.

No diagnóstico genético de pré-implantação, que tem como objetivo inicial evitar o risco de transmissão de doenças hereditárias, surgem dificuldades para delinear o limite entre a seleção de fatores hereditários indesejáveis e a otimização de fatores desejáveis 11 . A complexidade para estabelecer uma fronteira entre a prevenção de doenças hereditárias e o aperfeiçoamento do patrimônio hereditário, associada à insuficiência de parâmetros acerca do tema, em contraste à crescente abrangência do respectivo diagnóstico, fomenta importantes debates médicos, éticos e jurídicos.

A clonagem humana, por sua vez, tem gerado muitas discussões em razão das implicações sociais, éticas e jurídicas. Desse modo, a clonagem reprodutiva suscita reprovação na ciência, na política e na área jurídica, fundada particularmente na arguição de que a instrumentalização do ser humano pela criação deliberada de seres humanos geneticamente idênticos é contrária à dignidade humana 12,13. Quanto à clonagem terapêutica, atualmente novas técnicas permitem criar célulastronco equivalentes às embrionárias pelas células da pele, do que resulta a desnecessidade de utilizar e destruir embriões humanos para utilização terapêutica 14 .

Com relação às células-tronco embrionárias, os debates sobre a utilização do embrião para fins terapêuticos e de pesquisa recaem nas intervenções, agressões e destruição do embrião humano. No Brasil, a utilização de células-tronco embrionárias encontra-se regulada pelo artigo 5o da Lei no 11.105, de 24 de março de 2005 (Lei de Biossegurança) 15 . O referido dispositivo legal foi objeto de Ação Direta de Inconstitucionalidade no 3.510 16, que, em que pese a divergência dos votos acerca do marco inicial da vida, assim como referentes ao prazo de criopreservação e aos métodos alternativos existentes, foi julgada improcedente, por maioria de votos. Logo, é permitida a utilização, para fins de pesquisa e terapia, de células-tronco embrionárias obtidas de embriões humanos produzidos por fertilização in vitro, consideradas inviáveis e criopreservadas há mais de três anos.

As questões relacionadas à biologia sintética também se encontram no rol de inquietações porque a sociedade se depara com a possibilidade de redesenhar a vida existente e criar novas formas de vida em laboratório 17. Destacam-se as preocupações de a biologia sintética subverter o curso natural da evolução da espécie humana, bem como a utilização de procedimentos que podem gerar matéria viva nova ou desconhecida, com capacidade de replicação autônoma, de modo a exigir maior prudência, uma vez que não se pode prever e controlar as novas matérias vivas, que podem colocar em risco a biossegurança 18 .

Por fim, o sistema CRISPR-Cas9 tem potencial para curar doenças genéticas e até mesmo alterar características humanas. A técnica CRISPR, aplicada inicialmente na cultura de iogurtes e 
queijos ${ }^{19}$, posteriormente experimentada em camundongos 20 e na criação de macacos com mutações genéticas 21 , vem sendo utilizada em pesquisas para a edição de sequências de DNA em embriões humanos 22 . A ferramenta tem potencial eficácia no tratamento de doenças genéticas, entretanto, por se tratar de recente mecanismo, os cientistas 23 assinalam que é preciso analisar os riscos e os benefícios de sua implementação.

Segundo Hans Jonas 24, busca-se controlar a própria evolução, não somente para conservar a espécie em sua integridade, mas para melhorá-la e modificá-la de acordo com o projeto desenvolvido. Saber se se tem o direito e se é qualificado para esse papel criador é a pergunta mais séria que pode ser feita àqueles que se encontram na posse desse poder tão grande diante do destino. Conforme destaca o filósofo, a questão exige uma resposta antes que o cientista se deixe levar em uma viagem ao desconhecido.

Nesse contexto, Conill Sancho acentua que é necessário indagar acerca da ética presente na criação das novas biotecnologias. É preciso também refletir sobre o significado, para o ser humano, das transformações decorrentes da implementação dos respectivos avanços biotecnológicos, assim como das possibilidades e limites das inovações. O mencionado processo é de crescente relevância à medida que as intervenções biotecnológicas estão promovendo transformações no próprio modo de o ser humano entender a si mesmo 25 .

\section{Teorias sobre o marco inicial da vida humana}

Os avanços biotecnológicos acima mencionados desembocam especialmente em um dos temas mais controversos da atualidade: a definição do início da vida humana. As teorias sobre o marco inicial da vida perpassam os âmbitos científico, religioso, cultural, filosófico e jurídico. Trata-se de assunto que suscita questões de grande relevância e sobre o qual não há um denominador comum.

A Tabela 1 ilustra critérios utilizados para estabelecer um marco inicial da vida. Os respectivos parâmetros são baseados em diferentes características do desenvolvimento humano 26.

Entre os critérios mais utilizados para delimitar o marco inicial da vida humana destacam-se a concepção propriamente dita ou o surgimento do novo genoma, muito utilizados por coincidirem com o critério biológico; a nidação do embrião à parede do útero materno, por sua acolhida na comunidade humana; o surgimento das células cardíacas ou das células nervosas diferenciadas, utilizado por simetria aos critérios de morte cardíaca ou encefálica; a viabilidade pulmonar para a vida extrauterina, porquanto o feto teria condições de vida independente do suporte biológico materno 27.

Nas diferentes denominações religiosas e culturais, a delimitação do início da vida humana pode ser definida desde a concepção até o nascimento. Para a Ciência Cristã, não existe um início da vida, pois a mesma entende que a vida é eterna e inicia em Deus. Já o critério segundo o qual o marco inicial da vida ocorre na concepção é compartilhado pelo Budismo Tibetano, o Catolicismo Romano, o Espiritismo, o Zen-Budismo, o Islamismo, o Judaísmo, as Testemunhas de Jeová e religiões afro-brasileiras - Candoblé e Umbanda. O Luteranismo aceita o critério da concepção, mas considera fundamental a nidação do embrião no útero para caracterizar plenamente o início da vida. Os Ciganos e os indígenas Kaigang e Guarani entendem que o marco inicial ocorre quando a gestação é percebida. Por sua vez, os Santos dos Últimos Dias acreditam que o espírito entra no corpo na hora do nascimento, formando a alma da pessoa pela união entre espírito e corpo 28.

$\mathrm{Na}$ ética filosófica contemporânea, o modelo vitalista considera como pessoa humana o ser que possui o genoma humano, enquanto o modelo cultural exige, para que um ser seja considerado uma pessoa, uma possível manifestação, atual ou futura, de consciência moral e racionalidade, caracterizadas pela autonomia. Todavia, ambos os paradigmas estão sendo contestados, mediante o argumento de que não é possível buscar de forma absoluta os fundamentos ontológicos da pessoa, tanto pela ontologia substancial (ser racional), quanto por meio de uma ontologia relacional (atribuição de consciência e racionalidade por outra pessoa que, no caso de determinadas religiões, seria identificada como Deus). Assim, a crítica contemporânea busca libertar-se de uma reflexão unicamente teórico-abstrata e substituí-la por um debate sobre o melhor modo de tratar o embrião, sem considerar a questão ontológica 29. 
Tabela 1

Critérios utilizados para estabelecer o início da vida de um ser humano.

\begin{tabular}{|c|c|c|}
\hline Tempo decorrido & Característica & Critério \\
\hline 0 minuto & Fecundação; fusão de gametas & Celular \\
\hline $12-24$ horas & Fecundação; fusão dos pró-núcleos & Genotípico estrutural \\
\hline 2 dias & Primeira divisão celular & Divisional \\
\hline 3-6 dias & Expressão do novo genótipo & Genotípico funcional \\
\hline $6-7$ dias & Implantação uterina & Suporte materno \\
\hline 14 dias & Células do indivíduo diferenciadas das células dos anexos & Individualização \\
\hline 20 dias & Notocorda maciça & Neural \\
\hline 3-4 semanas & Início dos batimentos cardíacos & Cardíaco \\
\hline 6 semanas & Aparência humana e rudimento de todos os órgãos & Fenotípico \\
\hline 7 semanas & Respostas reflexas à dor e à expressão & Senciência \\
\hline 8 semanas & Registro de ondas eletroencefalográficas (tronco cerebral) & Encefálico \\
\hline 10 semanas & Movimentos espontâneos & Atividade \\
\hline 12 semanas & Estrutura cerebral completa & Neocortical \\
\hline $12-16$ semanas & Movimentos do feto percebidos pela mãe & Animação \\
\hline 20 semanas & Probabilidade de $10 \%$ para sobrevida fora do útero & Viabilidade extrauterina \\
\hline 24-28 semanas & Viabilidade pulmonar & Respiratório \\
\hline 28 semanas & Padrão sono-vigília & Autoconsciência \\
\hline 28-30 semanas & Reabertura dos olhos & Perceptivo visual \\
\hline 40 semanas & Gestação a termo ou parto em outro período & Nascimento \\
\hline 2 anos após o nascimento & “Ser moral" & Linguagem para comunicar vontades \\
\hline
\end{tabular}

Fonte: Goldim 26.

No sistema jurídico brasileiro, não há consonância no concernente à natureza jurídica do nascituro e ao momento a partir do qual lhe é atribuída personalidade civil. Nos intensos debates acerca do assunto, destacam-se as teorias: natalista, concepcionista e da personalidade condicional. A primeira defende que a personalidade tem início a partir do nascimento com vida e, portanto, há mera expectativa de direitos titularizada ao nascituro. A segunda entende que a personalidade jurídica inicia com a concepção, de modo que sustenta que o nascituro é pessoa e, portanto, sujeito de direitos, embora alguns direitos só possam ser plenamente exercidos a partir do nascimento. Para a terceira teoria, a personalidade inicia com o nascimento com vida, mas o nascituro titulariza direitos submetidos à condição suspensiva ou direitos eventuais 30 .

A propósito, o debate acerca do marco inicial da vida humana envolveu divergentes entendimentos acerca do tema na Ação Direta de Inconstitucionalidade no 3.510, que teve como objeto o artigo $5^{\circ}$ da Lei de Biossegurança, que autoriza a utilização de células-tronco embrionárias obtidas de embriões humanos excedentários produzidos por fertilização in vitro. Porém, as relevantes discussões não resultaram em uma definição com relação ao início da vida pelo Supremo Tribunal Federal 16. Por seu turno, o Superior Tribunal de Justiça, no julgamento do Recurso Especial no 1.415.727 - SC, ao tratar de acidente automobilístico que resultou em óbito fetal, conferiu a condição de pessoa ao nascituro 30 .

Enfim, em que pese um sem-número de critérios para definir o marco inicial da vida humana, nos diversos âmbitos da sociedade, não há consenso com relação ao assunto. Diante desse contexto, é importante observar que, conforme salienta José Roque Junges, o início da vida humana é uma realidade relacionada a profundos referenciais simbólicos, de modo que é indicada uma perspectiva hermenêutica que explicite os respectivos pressupostos e referenciais 31 .

Nesse âmbito, a ética hermenêutica proposta por Jesus Conill Sancho ${ }^{1}$ pode ser indicada como um importante modelo de abordagem. O respectivo processo hermenêutico, conforme se salientou inicialmente, possibilita uma reflexão crítica, utilizando como referencial os fundamentos éticos, para a análise das intervenções da biotecnologia que geram discussões com relação ao marco inicial da vida humana. 


\section{O estatuto do embrião}

A natureza humana é constituída pelas propriedades essenciais dos seres humanos e determina seu estatuto, que corresponde ao lugar na escala dos seres e na natureza. O estatuto influencia o comportamento e o tratamento direcionado aos seres humanos. Por isso, quanto mais elevado o estatuto do embrião, mais sólida deve ser a justificativa para a realização de alguma intervenção 12 .

Dessa maneira, os avanços da biotecnologia que possibilitam a manipulação, a criopreservação ou o descarte de embriões, desencadeiam muitas dúvidas no que se refere ao seu estatuto. Ao tratar do status do embrião, as opiniões divergem no sentido de considerá-lo como uma simples materialidade biológica, isso é, uma parte ou uma extensão do corpo humano, ou então um indivíduo da espécie humana ou, ainda, uma pessoa humana.

Nessa seara, Engelhardt Jr. 32 argumenta que as pessoas são diferentes dos seres humanos e que somente as primeiras mereceriam respeito. $\mathrm{O}$ autor aponta a autonomia como uma das propriedades fundamentais da pessoa humana e defende que o embrião e o feto não estariam inseridos em tal contexto. Assim, considera o embrião como uma extensão do corpo humano e propriedade daqueles que o produzem, de modo que podem atribuir valor ao embrião e dele dispor até o momento em que ele tome posse de si mesmo como entidade consciente ou torne-se pessoa.

De sua parte, Vincent Bourguet 33 argumenta que as tentativas no sentido de negar a individualidade biológica do embrião são eminentemente discutíveis, sendo necessário libertar-se da concepção unívoca e limitada da individualidade humana para reconhecer como humanas as diferentes estruturas do embrião. Nos estágios embrionários, o ser humano manifesta-se por estruturas e dimensões, e a individualidade humana constante nas respectivas estruturas leva a considerá-las também humanas.

Existem também divergências em considerar o embrião um indivíduo ou uma pessoa humana. $\mathrm{O}$ indivíduo é um conceito quantitativo relacionado à espécie humana e expressa o princípio da individuação perante o outro, vale dizer, o que faz diferenciar um do outro dentro da mesma espécie e gênero, de modo que representa um número. Por sua vez, a pessoa expressa a originalidade e a condição de mistério presente em cada ser humano, refere-se a uma realidade irredutível pela qual cada um é responsável diante de si e do outro. A pessoa não pode ser substituída, pois é única no mundo e possui uma história original que não pode ser repetida 31.

Em que pese o conceito de pessoa represente uma forma particular de se analisar o indivíduo, isso não implica a existência de uma pessoa apartada do indivíduo. Na própria definição de Boécio, "pessoa é a substância individual de natureza racional" 34, ou seja, a pessoa é um indivíduo dotado de razão. Portanto, subsiste na pessoa um indivíduo, embora o mesmo possa ser objeto de reflexão em diferentes âmbitos - moral, jurídico, psicológico, biológico, sociológico 35 .

O conceito de pessoa tem uma função distinta não compartilhada com o conceito de ser humano, que é considerado como entidade biológica. Surge, então, um grande dilema, uma vez que o indivíduo é percebido somente como ser humano e não como pessoa. Em busca de soluções, o debate bioético propõe muitas vezes abrir mão desse conceito ou ressignificá-lo, com intuito de valorar, moralmente, traços exclusivamente biológicos 35 . Tais aspectos, conforme se verá a seguir, adquirem grande relevância ao se tratar do embrião.

Indaga-se, então, o momento em que o ser humano se torna uma pessoa ou em que medida a individualidade do embrião merece respeito como pessoa. Trata-se de relevante discussão, em razão das arguições no sentido de que nem tudo no ser humano é humano por igual ou que nem todos os seres humanos são humanos no mesmo grau e, consequentemente, não exigem o mesmo respeito. Nesse caso, o zigoto e o embrião seriam exemplos de uma humanidade "menos humana" 33.

Nesse contexto, Bernard Baertschi 12 (p. 257) salienta que o embrião "é aquilo que se poderia chamar de uma pessoa potencial, pelo menos a partir do momento em que se tornou um indivíduo verdadeiro, ou seja, a partir da aparição da linha primitiva”. Logo, o embrião já possui em si a propriedade intrínseca necessária para se tornar uma pessoa. Em que pese sua importância, essa propriedade não confere ao embrião o estatuto de pessoa, de modo que os interesses de uma pessoa têm primazia sobre os interesses do embrião. Contudo, disso não decorre que se possa tratar o embrião como uma coisa ou, dito de outro modo, como um recurso que possui somente valor instrumental.

Na teoria kantiana, o respeito à dignidade está relacionado à humanidade tanto na própria pessoa como na do outro ser humano, isso é, deve-se respeito a todo aquele que faz parte da humanidade. 
Kant enfatiza que "todo ser humano tem um direito legítimo ao respeito de seus semelhantes e está, por sua vez, obrigado a respeitar todos os demais" 36 (p. 306). E acrescenta que a humanidade mesma é uma dignidade, de modo que um ser humano não pode ser usado meramente como um meio, tanto por outros como por si mesmo, mas sempre como um fim.

Segundo Emmanuel Levinas 37, as relações do ser humano com o "outro" deverão ser caracterizadas pela ética, em outras palavras, propõe uma ética da alteridade. Logo, o ser humano deverá acolher o outro para além da própria satisfação, respeitando as diferenças, no sentido do humanismo. Perfilhando o mencionado entendimento, Junges 31 ressalta que é preciso assumir esse paradigma relacional como ponto de partida e de compreensão do estatuto do embrião.

Nessa linha de entendimento, Conill Sancho 2 pondera acerca da importância de responsabilizar uns pelos outros e se cuidarem mutuamente. Trata-se, portanto, de uma ética de responsabilidade, na qual estão inseridas as éticas da fragilidade, da vulnerabilidade e do cuidado, com base na compaixão e no reconhecimento recíproco.

\section{A dignidade humana como referencial}

As reflexões relacionadas ao início da vida humana e ao estatuto do embrião desembocam em outro importante tema: a dignidade humana com relação ao embrião humano. No que se refere aos embriões na fase gestacional, a titularidade de direitos fundamentais é mais clara, entretanto, com relação a embriões que ainda não se encontram em fase gestacional, tais como embriões pré-implantados e excedentes, a questão é mais delicada e requer maior reflexão 38 .

Ao tratar dos valores básicos da existência humana, John Finnis 39 afirma que todas as sociedades humanas demonstram preocupação com o valor da vida humana. O primeiro valor básico do ser humano consiste no impulso da autopreservação, a saber, o valor da vida. O valor inclui a saúde corporal e a ausência de dor, assim como a propagação da vida pela procriação. Por conseguinte, as questões relativas ao início da vida humana assumem crescente relevância porque se referem ao valor básico da humanidade.

Entre os bens humanos básicos listados por Finnis 39 , encontra-se o bem da razoabilidade prática, no sentido da utilização adequada da inteligência humana, já que o modo como será aplicado o raciocínio prático em projetos, disposições e ações, levará ao resultado da participação da pessoa nos demais bens básicos 40 . A ética consiste na expressão dessa participação e das soluções reputadas razoáveis, considerando as reflexões sobre o passado e sobre um possível futuro 39.

$\mathrm{Na}$ mesma linha de raciocínio, Conill Sancho 2,25 constata que diante do progresso da técnica em todos os âmbitos, inclusive em sua determinação da razoabilidade prática, é necessário refletir e propor medidas que valorizem e promovam uma orientação responsável do crescente poder dos avanços biotecnológicos. Portanto, é necessária uma postura da ética que esteja à altura da vida contemporânea, ou seja, conforme mencionamos anteriormente, uma ética de responsabilidade.

A propósito, Hans Jonas 24 elabora uma proposta ética por meio do princípio da responsabilidade que assinala a necessidade de que a conduta da pessoa humana seja compatível com o futuro da humanidade. Dito de outro modo, as novas formas do agir humano mediante o uso da técnica requerem limites, à proporção que podem interferir no próprio ser humano e nas outras gerações. Logo, é preciso assumir um compromisso com a dignidade humana e o futuro da humanidade. A propósito, conforme preconizam Martins-Costa \& Möeller 41 (p.XII), "entre bioética e responsabilidade, os nexos são, pois, imediatos, estando todos nós na posição de 'garantes do futuro', devedores que somos de um pensar e de um agir responsável perante nós mesmos, o nosso porvir e a nossa espécie".

Em razão disso, a dignidade humana constitui um dos fundamentos contra o desenvolvimento tecnocientífico ilimitado que, aliado aos interesses do mercado, gera potencial risco de desumanização 29. Como bem assinala Roberto Andorno 42 (p. 83-4), "a noção de dignidade humana desempenha o papel de ideia diretriz da ética biomédica" e, nesse âmbito, a formulação kantiana de dignidade humana se torna de grande utilidade e facilita a busca de respostas aos problemas bioéticos.

Na concepção kantiana, o ser humano é considerado como um fim em si mesmo, de modo que a pessoa deve ser tratada sempre como um fim e não como um simples meio. Ademais, a dignidade não tem preço; em consequência, não poderá ser substituída por qualquer coisa equivalente ${ }^{36}$. Assim, a 
ideia de dignidade humana na sociedade tecnocientífica contemporânea busca seus fundamentos no pensamento kantiano, precipuamente no sentido de afastar a coisificação e instrumentalização do ser humano 38 .

$\mathrm{Na}$ esteira do pensamento kantiano, Heloisa Helena Barboza 8 indica como possibilidade para enfrentar os problemas bioéticos relacionados ao início da vida humana, conferir ao embrião, com base no princípio da dignidade humana, uma tutela particular que não permita sua instrumentalização. Enfim, dar ao embrião uma proteção condizente com o respeito por conta de um ser humano que não pode ser coisificado.

É imprescindível uma convergência entre a liberdade da ciência e a dignidade humana, pois a liberdade encontra no respeito à dignidade humana o critério determinante para sua legitimidade. A liberdade científica e a dignidade humana podem e devem se relacionar de modo harmônico 42 , no entanto é preciso que essa liberdade esteja condicionada a parâmetros éticos e jurídicos, de modo que seja oportuno o desenvolvimento tecnocientífico e, ao mesmo tempo, assegurada a dignidade humana do embrião.

Portanto, são necessários instrumentos que possibilitem a utilização da biotecnologia sem desrespeitar o embrião e a natureza humana. Nesse contexto, a ética hermenêutica pode ser indicada como uma importante ferramenta, utilizando a dignidade humana como referencial.

Conforme salienta Celso de Mello 16, compete ao intérprete optar pela concepção que mais se ajuste ao interesse público, às exigências sociais do desenvolvimento tecnocientífico e ao bem-estar da coletividade, objetivando conferir sentido real ao princípio da dignidade da pessoa humana e efetividade aos dispositivos constitucionais do direito à vida e à saúde. A Constituição brasileira assegura a inviolabilidade do direito à vida no artigo 5o, caput, entretanto não veicula qualquer conceito normativo da vida humana e muito menos define o marco inicial da existência humana, o que abre espaço para dispor sobre as questões relacionadas ao início da vida.

No contexto da sociedade hodierna, conforme se verificou no presente estudo, torna-se relevante uma nova abordagem hermenêutica, mormente diante das indefinições acerca do início da vida humana, dos crescentes avanços da biotecnologia, da pluralidade e da diversidade cultural. Mediante a ética hermenêutica crítica, Conill Sancho ${ }^{1}$ aponta a necessidade de desvelar a riqueza da moral na vida fática, na qual está situada a experiência de alteridade recíproca e de reconhecimento mútuo.

Enfim, um dos maiores desafios para a ética da responsabilidade na sociedade tecnocientífica contemporânea é considerar a dignidade humana como o princípio central em torno do qual buscamos responder à pergunta sobre as pessoas que queremos ser e a sociedade que pretendemos construir 29. Verifica-se, pois, que a dignidade humana pode ser indicada como um adequado referencial hermenêutico para a construção de parâmetros éticos e jurídicos aos avanços biotecnológicos que dão causa aos questionamentos relacionados ao marco inicial da vida humana.

\section{Considerações finais}

Ao perquirir sobre questões éticas e jurídicas no tocante ao marco inicial da vida humana, constata-se que existem muitos critérios científicos para definir o início da vida que apontam, para tanto, diferentes fases do desenvolvimento humano. Do mesmo modo, há inúmeras denominações religiosas, culturais, filosóficas e jurídicas, que utilizam diferentes fundamentos e manifestam divergentes posicionamentos com relação ao assunto. Em que pese o grande número de critérios e teorias, não existe consenso com relação ao assunto, vale dizer, não se tem uma resposta exata acerca do marco inicial da vida humana.

Por sua vez, o progresso da ciência e da técnica ocorre em ritmo acelerado e com inovações crescentes que intervêm nas fases iniciais da vida humana. Antes mesmo de a sociedade tomar conhecimento, ponderar e adotar providências com relação às possibilidades existentes, crescentes avanços da biotecnologia desencadeiam situações novas e sem precedentes, carecedoras de parâmetros para nortear sua utilização.

Portanto, no contexto da sociedade tecnocientífica contemporânea, aponta-se, aqui, a importância de refletir e dialogar mediante uma ética hermenêutica crítica, com a nova realidade decorrente do progresso científico e as questões relacionadas à (in)definição do marco inicial da vida humana. A 
dignidade humana pode ser indicada como um importante referencial hermenêutico nas respectivas reflexões e diálogos, bem como nos processos de construção de parâmetros éticos e jurídicos para nortear os respectivos avanços biotecnológicos.

\section{Colaboradores}

E. C. U. Lauxen redigiu o artigo. V. P. Barretto revisou o artigo. Ambos os autores aprovaram a versão final a ser publicada.

\section{Referências}

1. Conill Sancho J. Ética hermenéutica: crítica desde la facticidad. 2a Ed. Madrid: Tecnos; 2010.

2. Conill Sancho J. A manutenção da subjetividade humana diante do impulso tecnocientífico instrumental. IHU On-Line 2015; (456). http://www.ihu.unisinos.br/index.php?op tion $=$ com_content $\&$ view $=$ article $\& i d+5719 \&$ secao+456.

3. Conill Sancho J. Bioética e biopolítica na perspectiva hermenêutica: uma ética do cuidado e da vida. Cadernos IHU Ideias (Unisinos) 2015; 13:2-22.

4. Dworkin R. Domínio da vida: aborto, eutanásia e liberdades individuais. São Paulo: Editora Martins Fontes; 2003. 
5. Cortina A, Martínez E. Ética. 2a Ed. São Paulo: Edições Loyola; 2009.

6. Sandel MJ. Contra a perfeição: ética na era da engenharia genética. Rio de Janeiro: Civilização Brasileira; 2013.

7. Buchanan A, Brock DW, Daniels N, Wikler D. From chance to choice: genetics and justice. Cambridge: Cambridge University Press; 2000.

8. Barboza HH. Proteção jurídica do embrião humano. http://www.ghente.org/temas/re producao/protecao.htm (acessado em 02/ Jun/2015).

9. Brasil. Lei no 10.406, de 10 de janeiro de 2002. Institui o Código Civil. Diário Oficial da União 2002; 11 jan.

10. Conselho Federal de Medicina. Resolução CFM no 2.121/2015. Adota as normas éticas para utilização das técnicas de reprodução assistida - sempre em defesa do aperfeiçoamento das práticas e da observância aos princípios éticos e bioéticos que ajudarão a trazer maior segurança e eficácia a tratamentos e procedimentos médicos - tornando-se o dispositivo deontológico a ser seguido pelos médicos brasileiros e revogando a Resolução CFM no 2.013/13, publicada no D.O.U. de 9 de maio de 2013, Seção I, p. 119. Diário Oficial da União 2015; 24 set.

11. Habermas J. O futuro da natureza humana: a caminho de uma eugenia liberal? São Paulo: Editora Martins Fontes; 2004.

12. Baertschi B. Ensaio filosófico sobre a dignidade. São Paulo: Edições Loyola; 2009.

13. Junges JR. Bioética: perspectivas e desafios. São Leopoldo: Editora Unisinos; 2005.

14. Ian Wilmut desiste de clone terapêutico. http://www.ihu.unisinos.br/noticias/noticias -anteriores/10805-ian-wilmut-desiste-de-clo ne-terapêutico (acessado em 12/Nov/2015).
15. Brasil. Lei no 11.105, de 24 de março de 2005 . Regulamenta os incisos II, IV e V do $\$ 1$ o do art. 225 da Constituição Federal, estabelece normas de segurança e mecanismos de fiscalização de atividades que envolvam organismos geneticamente modificados - OGM e seus derivados, cria o Conselho Nacional de Biossegurança - CNBS, reestrutura a Comissão Técnica Nacional de Biossegurança - CTNBio, dispõe sobre a Política Nacional de Biossegurança - PNB, revoga a Lei no 8.974, de 5 de janeiro de 1995, e a Medida Provisória no 2.1919 , de 23 de agosto de 2001, e os arts. 5o, 6o, 7o, 8o, 9o, 10o e 16o da Lei no 10.814 , de 15 de dezembro de 2003, e dá outras providências. Diário Oficial da União 2005; 28 mar.

16. Supremo Tribunal Federal. Ação Direta de Inconstitucionalidade no 3.510 Distrito Federal. http://redir.stf.jus.br/paginadorpub/pagina dor.jsp? docTP=AC\&docID=611723 (acessado em 21/Jun/2015).

17. Diéguez-Lucena A. Biotecnologia e responsabilidade: para além do Prometeu moderno. IHU On-Line 2013; (429). http://www.ihuon line.unisinos.br/media/pdf/IHUOnlineEdi cao429.pdf.

18. Romeo-Casabona CM. Biotecnologia sob a ótica dos princípios jurídicos. IHU On-Line 2013; (429). http://www.ihuonline.unisinos. $\mathrm{br} / \mathrm{media} / \mathrm{pdf} / \mathrm{IHUOnlineEdicao} 429$.pdf.

19. Grens K. There's CRISPR in your yogurt: we've all been eating food enhanced by the genome-editing tool for years. Scientist 2015 29(1). http://www.the-scientist.com/?articles. view/articleNo/41676/title/There-s-CRISPRin-Your-Yogurt/.

20. Yin H, Xue W, Chen S, Bogorad RL, Benedetti E, Grompe M, et al. Genome editing with Cas9 in adult mice corrects a disease mutation and phenotype. Nat Biotechnol 2014; 32: 551-3. 
21. Niu Y, Shen B, Cui Y, Chen Y, Wang J, Wang $\mathrm{L}$, et al. Generation of gene-modified cynomolgus monkey via Cas9/RNA-mediated gene targeting in one-cell embryos. Cell 2014; 156:836-43.

22. Liang $\mathrm{P}, \mathrm{Xu} \mathrm{W}$, Zhang $\mathrm{X}$, Ding $\mathrm{C}$, Huang $\mathrm{R}$, Zhang Z, et al. CRISPR/Cas9-mediated gene editing in human tripronuclear zygotes. Protein Cell 2015; 6:363-72.

23. Carvalho TG, Matte US, Giugliani R, Baldo G. Genome editing: potential treatment for lysosomal storage diseases. Curr Stem Cell Rep 2015; 1:9-15.

24. Jonas H. O princípio responsabilidade: ensaio de uma ética para a civilização tecnológica. Rio de Janeiro: Contraponto; 2006.

25. Conill Sancho J. Hoje a grande ideologia é a ciência e a técnica. IHU On-Line 2014; (457). http://www.ihu.unisinos.br/noticias/536578jesus-conill-hoje-a-grande-ideologia-e-aciencia-e-a-tecnica.

26. Goldim JR. Início da vida de uma pessoa humana. http://www.bioetica.ufrgs.br/inivida. htm (acessado em 15/Dez/2015).

27. Goldim JR. Aspectos bioéticos no ciclo vital. In: Eizirik CL, Bassols AMS, organizadores. O ciclo da vida humana: uma perspectiva psicodinâmica. 2a Ed. Porto Alegre: Editora Artmed; 2012. p. 31-40.

28. Goldim JR, Salgueiro J, Raymundo MM, Matte U, Boer APK, organizadores. Bioética e espiritualidade. Porto Alegre: EdiPUCRS; 2007.

29. Barretto VP. O fetiche dos direitos humanos e outros temas. 2a Ed. Porto Alegre: Livraria do Advogado; 2013.

30. Superior Tribunal de Justiça. Ação de cobrança de seguro obrigatório. Recurso Especial no 1.415 .727 - SC (2013/03604913). http://ww2.stj.jus.br/processo/revista/ documento $/$ mediado/? componente $=$ AT C\&sequencial $=39138375 \&$ num_regis $\operatorname{tro}=201303604912 \&$ data $=20140929 \&$ tipo $=5$ \&formato $=$ PDF (acessado em 21/ Jun/2015)
31. Junges JR. Bioética: hermenêutica e casuística. São Paulo: Edições Loyola; 2006.

32. Engelhardt Jr. TH. Fundamentos da bioética. São Paulo: Edições Loyola; 1998

33. Bourguet V. O ser em gestação: reflexões bioéticas sobre o embrião humano. São Paulo: Edições Loyola; 2002.

34. Boécio. Sobre la persona y las dos naturalezas. In: Fernández C. Los filosofos medievales: selección de textos. Tomo 1. Madrid: BAC; 1979.

35. Barretto VP, Bragato FF. Leituras de filosofia do direito. Curitiba: Juruá; 2013.

36. Kant I. Fundamentação da metafísica dos costumes. São Paulo: Discurso Editorial/Barcarolla; 2009.

37. Levinas E. Totalidade e infinito. Lisboa: Edições 70; 1980.

38. Sarlet IW. A eficácia dos direitos fundamentais. 11a Ed. Porto Alegre: Livraria do Advogado; 2012.

39. Finnis J. Lei natural e direitos naturais. São Leopoldo: Editora Unisinos; 2007.

40. Engelmann W. Direito natural, ética e hermenêutica. Porto Alegre: Livraria do Advogado; 2007.

41. Martins-Costa J, Möeller LL, organizadoras. Bioética e responsabilidade. Rio de Janeiro: Forense; 2009.

42. Andorno R. "Liberdade" e "dignidade" da pessoa: dois paradigmas opostos ou complementares na bioética? In: Martins-Costa J, Möller LL, organizadoras. Bioética e responsabilidade. Rio de Janeiro: Forense; 2009. p. 73-93. 


\section{Abstract}

Questions concerning the beginning of human life have pervaded society since antiquity. In the post-modern world, scientific and technological advances have fueled discussions on the issue, such that debates previously concentrated on abortion now also focus on biotechnological interventions. The article addresses the latter, reflecting on the extent to which human dignity can be considered a (hermeneutic) reference in establishing ethical and legal parameters for biotechnological advances in the definition of the beginning of human life. The study's method was critical hermeneutic ethics, with ethics at the center of the process of understanding and interpretation, observing the contours of facticity. No consensus was found on the beginning of human life, so it is essential to engage in dialogue with the new reality resulting from biotechnological advances in the process of defining ethical and legal principles for protecting the embryo and human nature, with human dignity as the reference.

Human Embryo; Biotechnology; Bioethics

\section{Resumen}

Las investigaciones relacionadas con el inicio de la vida humana han acompañado a la sociedad desde la antigüedad. En el mundo posmoderno, los avances de la ciencia y de la técnica potencian las discusiones sobre este tema, de modo que los debates que anteriormente se concentraban en torno al aborto, también pasaron a ser objeto por las intervenciones de la biotecnología. El presente artículo trata acerca de este último aspecto, a saber, reflexionar en qué medida la dignidad humana puede ser considerada una referencia (hermenéutica) en la construcción de parámetros ético-jurídicos para los avances biotecnológicos, en la definición del marco inicial de la vida humana. Para desarrollar la investigación, se utilizó como método de enfoque la ética hermenéutica crítica, mediante la cual la ética se encuentra en el centro del proceso de comprensión e interpretación, observándose los contornos de la facticidad. Se constató que no existe consenso en lo que se refiere al término inicial de la vida, de forma que es fundamental dialogar con la nueva realidad, derivada de los avances biotecnológicos, en el proceso de construcción de preceptos éticos y jurídicos de protección del embrión $y$ de la naturaleza humana, teniendo como referente la dignidad humana.

Embrión Humano; Biotecnología; Bioética
Recebido em 29/Abr/2016

Versão final reapresentada em 07/Jul/2016 Aprovado em 24/Ago/2016 